\title{
Importance of Applying Potassium to Reduce the Cracking Rate of Pomegranate Fruits
}

\author{
${ }^{1}$ Dr. Rida DRAIE; ${ }^{2}$ Ali ABORAS \\ ${ }^{1}$ Faculty of Agricultural Engineering, University of Idlib, Syria \\ ${ }^{2}$ Postgraduate Student, MA, Faculty of Agricultural Engineering, University of Idlib, Syria
}

\begin{abstract}
The research was carried out in the 2018 agricultural season with the aim of studying the effect of foliar spraying with potassium on reducing the fruit cracking of pomegranate. The experiment was conducted according to the completely randomized design (CRD). We had three treatments for potassium concentrations $(0$, $1000,2000 \mathrm{ppm}$ ) and four treatments for the number of spraying times $(0,1,2$, and 3 times). The results showed that all potassium spraying treatments exceeded the control in most of the studied characteristics. The increase in the spraying concentration achieved a significant reduction in the percentage of fruit cracking, which amounted to $22.98 \%$ and $19.75 \%$ in the treatments of concentrations $A$ and $B$, respectively. The increase in the number of foliar spraying with potassium also reduced the percentage of fruit cracking, as it reached $73.96 \%$, $28.32 \%, 21.03 \%$, and $17.57 \%$ in treatments of $0,1,2$, and 3 spraying times, respectively. Similarly, the productivity was greatly increased by the effect of potassium foliar spraying.
\end{abstract}

Keywords: Fruit Cracking, Pomegranate, Potassium, Foliar Spraying, Concentration, Number of Spraying Times.

\section{INTRODUCTION}

Pomegranate is grown in Syria to a good degree. The production covers the needs of the local market with the export of a small portion of production. However, pomegranate cultivation is exposed to many problems that affect the quantity and quality of production, where the most important of these problems is the fruit cracking. The degree of sensitivity to this disorder varies according to the variety. The French variety is considered one of the most important cultivated varieties in northern Syria in terms of the cultivated area and in terms of consumption of the fruits of this variety. However, due to the sensitivity of this variety to the fruit cracking, the areas planted with it decreased and the trend towards other tree species began (Draie and Aboras, 2021a).

Fruit cracking is one of the most important physiological problems affecting pomegranate fruits (Malhotra et al., 1983). As the cracked fruits are not desirable to the consumer. In addition to the high percentage of this disorder in some varieties of pomegranate and in some years, it leads to reluctance to reap the fruits. Where Panwar et al. (1994) and Singh (1995) showed that when the fruits crack, they are susceptible to infection with bacteria and fungi, and thus lose their marketing value and may become unfit for human consumption, which causes a very large economic loss for pomegranate farmers and marketers alike (Finkel and Holbrook, 2000; Schrader et al., 2002). (Singh et al., 2006; Bankar and Prasad, 1992) confirmed that the majority of fruits crack at the time of ripening, and these fruits lose their quality and become unfit for marketing and thus cause a great loss in production. The cracking rate varies between $10-70 \%$, which reduces production to $50 \%$, and this is harmful to the farmer (Anonymous, 1983, Draie and Aboras, 2021b).

The degree of cracking varies according to the stages of the growth of the fruit, so cracking is more pronounced at the stage of ripeness (Hoda and Hoda, 2013; Shulman et al., 1984; Yazici and Kaynak, 2006). The cause of pomegranate cracking is mainly due to genetic factors (variety), in addition to environmental factors, and various agricultural treatments (Saad et al., 1988; Prasad et al., 2003; Chandra et al., 2011; Khadivi-Khub, 2014). The correlation of the problem of cracking of pomegranate fruits with irregular irrigation and lack of nutrients has been confirmed (Gharesheikhbayat, 2006; Khalil and Aly, 2013; Saei et al., 2014; Galindo et al., 2014). Abd and Rahman (2010) also indicated that the cracking is associated with high temperature, high transpiration rate, low humidity in the air and soil, and sharp fluctuations in temperature between day and night during fruit growth.

Lack of mineral nutrition such as potassium is directly related to fruit cracking in pomegranates (Gharesheikhbayat, 2006; Saei et al, 2014). Nutrients such as potassium are involved in some physiological processes during the period of fruit growth, and their deficiency leads to fruit cracking (Sheikh and Manjula, 2009). Sheikh and Manjula (2009) found that the addition of N, P, K fertilizers in 3 batches (200; $200 ; 400 \mathrm{~g}$ per plant) gave the highest productivity of the pomegranate tree, of the average weight of the fruit, of the percentage of juice, as well as an increase in the percentage of T.S.S. and sugars and vitamin C, compared to the fewer 
ISSN (online): 2581-3048

Volume 5, Issue 5, pp 1-9, May-2021

https://doi.org/10.47001/IRJIET/2021.505001

additions of fertilizers. Abdel-Aziz et al. (2001) also confirmed that irrigating of Manfalouty pomegranate variety four times with potassium sulfate at a concentration of $0.5 \%$ and potassium chloride at a concentration of $0.5 \%$ alone or as a mixture, which improved productivity and reduced the percentage of fruit cracking.

Accordingly, this research was conducted, with the aim of studying the cracking of the pomegranate fruits in the French variety in order to preserve this locally desired variety and to study the feasibility of using different concentrations and a different number of spraying times of potassium in the possibility of reducing the cracking of the fruits of this variety.

\section{MATERIALS AND METHODS}

\subsection{Experimental Location}

This research was carried out in 2018 in an orchard planted with pomegranate trees in the city of Sarmada, which is located on the Syrian-Turkish border. The city of Sarmada is about $40 \mathrm{~km}$ to the north of Idlib, and it is approximately 383 meters high. The total rainfall during the research season was $693 \mathrm{~mm}$.

\subsection{Plant Materials}

The experiment was conducted on French pomegranate trees, which have large, spherical to flattened fruits, with red skin and long necks. The seeds are surrounded by a bloody red pulp, the leaf is elongated, and the branches are spiny. The fruits of this variety are prone to cracking (Draie and Aboras, 2021a;b).

\subsection{Experimental Design and treatments}

The study was executed in the 2018agricultural season in a field planted with French pomegranate trees at the age of 10 years and dimensions $4 \times 4 \mathrm{~m}$. The complete randomized design (CRD) was used.

The experiment included three treatments for the concentrations of potassium and four treatments for the number of foliar spraying times with potassium, according to the following:

- Potassium solution concentrations: 0, 1000 ppm (A), and 2000 ppm (B).

- Number of foliar spraying times: 0, 1, 2, and 3 times:

- Control without spraying.

- Foliar spraying once after the beginning of flowering (1/5/2019).

- Foliar spraying twice after the beginning of flowering (1/5/2019) and after the completion of the fruit set (1/6/2019).
- Foliar spraying three times after the beginning of flowering (1/5/2019), after the completion of the fruit-set $(1 / 6 / 2019)$, and when the fruits start to color $(1 / 7 / 2019)$.

Five replicates per treatment, with one tree (French pomegranate variety) per replicate, were adopted. Consequently, the number of pomegranate trees used in the experimentation $=3$ concentrations $\mathrm{x} 4$ foliar spraying times $\mathrm{x}$ 5 replicates $x 1$ tree $=60$ trees.

\subsection{Measured Parameters}

The following measurements were taken:

\section{Flowering traits}

- Number of days until the starting of flowering.

- Number of total flowers.

- Number of hermaphrodite flowers.

- Ratio of hermaphroditic flowers (\%).

\section{Fruits-set and Yield characteristics}

- Ratio of fruit-set (\%).

- Number of days until the date of fruits ripening.

- Productivity kg/tree.

\section{Physical properties of fruits}

- Ratio of cracked fruits per tree (\%).

- Diameter of fruit (cm).

- Weight of fruits (kg).

- Weight of fruit peel $(\mathrm{g})$.

- Internal tissue weight $(\mathrm{g})$.

- Weight of seeds (g).

- Weight of juice (g).

\section{Fruit quality characteristics}

- Ratio of juice (\%).

- Total Soluble Solids (T.S.S.\%).

- Acidity of juice (pH).

\subsection{Statistical analysis}

The results were analyzed by the statistical program (GenStat-12). The averages were compared by calculating the LSD at the level of significance $(5 \%)$.

\section{RESULTS AND DISCUSSION}

3.1 Effect of spraying concentration with potassium on the studied characteristics 
Table (1): Effect of spraying concentration with potassium on the studied characteristics

\begin{tabular}{|l|c|c|c|c|}
\hline \multicolumn{1}{|c|}{ Concentration (ppm) } & $\mathbf{0}$ & $\mathbf{1 0 0 0}$ & $\mathbf{2 0 0 0}$ & LSD $_{\mathbf{5}}$ \\
\hline Trait & 52.00 & 51.00 & 50.50 & 0.11 \\
\hline Flowering & 151.00 & 148.50 & 147.25 & 0.12 \\
\hline Ripening & 287.33 & 416.64 & 452.38 & 1.89 \\
\hline Number of total flowers & 25.75 & 40.82 & 41.75 & 0.43 \\
\hline Hermaphrodite flowers (\%) & 21.62 & 34.42 & 36.90 & 1.1 \\
\hline Fruit-set (\%) & 8.32 & 11.36 & 11.80 & 0.14 \\
\hline Diameter of fruit (cm) & 256.12 & 349.29 & 380.70 & 1.33 \\
\hline Weight of fruits (g) & 60.99 & 77.51 & 81.72 & 0.58 \\
\hline Weight of fruit peel (g) & 59.12 & 72.16 & 74.78 & 0.84 \\
\hline Internal tissues weight (g) & 136.01 & 199.62 & 224.20 & 1.26 \\
\hline Weight of seeds (g) & 27.32 & 39.36 & 41.93 & 0.19 \\
\hline Ratio of juice (\%) & 2.98 & 3.37 & 3.45 & 0.03 \\
\hline Acidity of juice (pH) & 15.22 & 15.81 & 16.54 & 0.17 \\
\hline Total Soluble Solids (T.S.S.\%) & 11.36 & 13.09 & 15.23 & 1.2 \\
\hline Productivity/tree (kg) & & & &
\end{tabular}

It is evident from Table (1) that all potassium foliar spraying concentrations exceeded the control in the number of days required to reach flowering (the value in the control was 52 days). The treatment of concentration B (2000 ppm) by 50.50 days outperformed the treatment of concentration A (1000 ppm) by 51.00 days in the mentioned trait. Also, the foliar spraying concentrations outperformed the control in reaching the ripeness of the fruits, as the control needed 151 days, and the increase in the used concentration led to significant differences between the spraying treatments themselves. As the treatment of concentration B (2000 ppm) by 147.25 days exceeded the treatment of concentration $\mathrm{A}$ (1000 ppm) by 148.50 days.

The total number of flowers in the control was 287.33 , in which the percentage of hermaphrodite flowers was $25.75 \%$. While, the treatment of concentration A achieved a significant difference on the control with 416.64 flowers, which was also superior to the percentage of hermaphroditic flowers, which amounted to $40.82 \%$. Whereas the treatment of concentration $B$ achieved a significant difference on the treatment of concentration A with the total flowers of 452.38 flowers, and by the percentage of hermaphrodite flowers which amounted to $41.75 \%$, (Table 1). Our study was in agreement with Shaheen (1995) who showed that increasing the spraying concentration led to an increase in the percentage of hermaphroditic flowers in pomegranate.

With regard to fruit-set, Table (1) shows that the percentage of fruit-set was $21.62 \%$ in the control, $34.42 \%$ in the treatment of concentration A (1000 ppm), and 36.90\% in the treatment of concentration B (2000 ppm), where the differences were significant between all treatments. Our study is consistent with Ozkaya (2004) who found that foliar spraying with trace elements has a positive effect in increasing fruit-set through its positive role in increasing cell division and activating the biosynthesis of organic compounds. Likewise, the use of a mixture of NPK led to a remarkable increase in the quality of fruits, fruit-set and production of pomegranate fruits (Singh et al., 1987).

The results in the Table (1) show the significant effect of the concentrations used in the weight of the peel and the weight of the internal tissues of the fruit, as their weight in the control reached $60.99 \mathrm{~g}$ and $59.12 \mathrm{~g}$, respectively. The treatments of concentrations A and B achieved a significant difference on the control. As the weight of the peel was $77.51 \mathrm{~g}$ and the weight of the internal tissues was $72.16 \mathrm{~g}$ in the treatment of concentration $\mathrm{A}$, while the weight of the peel was $81.72 \mathrm{~g}$ and the weight of the internal tissues was $74.78 \mathrm{~g}$ in the treatment of concentration $\mathrm{B}$, with a significant superiority of the treatment of concentration $\mathrm{B}$ on the treatment of concentration A.

The effect of potassium foliar spraying had a significant effect on the weight and diameter of the pomegranate fruit, where the weight of the fruit in the control reached $256.12 \mathrm{~g}$ and the diameter was $8.32 \mathrm{~cm}$. The treatment of concentration A achieved a significant difference on the control, as the weight of the fruit was $349.29 \mathrm{~g}$ and the diameter of the fruit was $11.36 \mathrm{~cm}$. Also, the treatment of concentration B achieved a significant difference on the treatment of concentration $\mathrm{A}$, in which the weight of the fruit was $380.70 \mathrm{~g}$ and the diameter of the fruit was $11.80 \mathrm{~cm}$. The weight of the seeds was also increased by the effect of foliar spraying with potassium, reaching $136.01 \mathrm{~g}, 199.62 \mathrm{~g}$, and $224.20 \mathrm{~g}$ in each of the control, the treatment of concentration $\mathrm{A}$, and the treatment of concentration B, respectively (Table 1). This agrees with Sheikh and Manjula (2009) who confirmed that foliar fertilization with potassium gave the highest average fruit weight. 
As for the percentage of juice, all potassium spraying concentrations outperformed the control treatment, in which the juice percentage was $27.32 \%$. The treatment of concentration B (2000 ppm) outperformed the treatment of concentration A (1000 ppm) with juice percentage of $41.93 \%$ and $39.36 \%$, respectively, (Table 1). Our study coincides with Fayed (2010), who showed that increasing the spraying concentration of Manfalouty pomegranate variety from 700 ppm to $1000 \mathrm{ppm}$, led to a significant increase in the percentage of juice in the fruit, and all treatments were superior on the control.

The acidity of the juice decreased (the $\mathrm{pH}$ increased) due to the effect of the foliar spraying with potassium, as the $\mathrm{pH}$ values reached $2.98,3.37$, and 3.45 in the treatment of the control, in the treatment of concentration A (1000 ppm), and in the treatment of concentration B (2000 ppm), respectively. Where the differences were significant between all treatments (Table 1).

The percentage of T.S.S. also increased due to the effect of potassium foliar spraying, as its value in the control reached $15.22 \%$. All the treatments significantly outperformed the control treatment, as the total T.S.S. percentage in the treatment of concentration B reached $16.54 \%$, which surpassed the treatment of concentration $\mathrm{A}$, in which the percentage of T.S.S. reached $15.81 \%$, (Table 1). Our results are consistent with studies that showed that fertilizing pomegranate trees with calcium, potassium, and boron, alone or in combination, improved the physical and chemical properties of the fruits (Abdel-Aziz et al., 2001).

Table (1) also indicates the significant effect of spraying with potassium on the productivity of the French pomegranate variety, as the productivity in the control reached 11.36 $\mathrm{kg} / \mathrm{tree}$. The treatment of concentration A (1000 ppm) achieved a significant increase over the control, with a yield of $13.09 \mathrm{~kg} /$ tree. The treatment of concentration B (2000 ppm) achieved a significant increase over the treatment of concentration A, with a productivity of $15.23 \mathrm{~kg} /$ tree. Where the differences were significant between all treatments. The spraying treatments achieved an increase in productivity over the control by $115.23 \%$ and $134.07 \%$ in the treatments of concentrations A and B, respectively. Our study is consistent with Sheikh and Manjula, (2009) who concluded that adding potassium to pomegranate trees gave the highest yield.

\subsection{Effect of spraying times with potassium on the studied characteristics}

Table (2): Effect of spraying times with potassium on the studied characteristics

\begin{tabular}{|l|c|c|c|c|c|}
\hline Trait & $\mathbf{0}$ & $\mathbf{1}$ & $\mathbf{2}$ & $\mathbf{3}$ & LSD $_{\mathbf{5} \%}$ \\
\hline Flowering & 52.00 & 51.25 & 51.00 & 50.75 & 0.13 \\
\hline Ripening & 151.00 & 149.50 & 148.75 & 147.50 & 0.15 \\
\hline Number of total flowers & 287.33 & 362.75 & 424.93 & 449.97 & 2.02 \\
\hline Hermaphrodite flowers (\%) & 25.75 & 38.94 & 40.75 & 41.66 & 0.50 \\
\hline Fruit-set (\%) & 21.62 & 33.25 & 35.50 & 36.23 & 1.04 \\
\hline Diameter of fruit (cm) & 8.32 & 11.20 & 11.38 & 11.71 & 0.11 \\
\hline Weight of fruits (g) & 256.12 & 322.65 & 349.89 & 371.34 & 1.58 \\
\hline Weight of fruit peel (g) & 60.99 & 75.60 & 77.56 & 79.84 & 0.67 \\
\hline Internal tissues weight (g) & 59.12 & 65.12 & 71.17 & 73.37 & 0.75 \\
\hline Weight of seeds (g) & 136.01 & 181.93 & 201.16 & 218.13 & 1.37 \\
\hline Ratio of juice (\%) & 27.32 & 38.27 & 40.37 & 41.54 & 0.24 \\
\hline Acidity of juice (pH) & 2.98 & 3.31 & 3.36 & 3.45 & 0.02 \\
\hline Total Soluble Solids (T.S.S.\%) & 15.22 & 15.72 & 16.05 & 16.58 & 0.19 \\
\hline Productivity/tree (kg) & 11.36 & 12.66 & 14.02 & 14.58 & 1.07 \\
\hline
\end{tabular}

The Table (2) shows that all spraying treatments exceeded the control in the number of days required to reach flowering (as the value in the control was 52 days). The increase in the number of spraying times also had a positive effect in this trait. The treatment of three-time spraying by 50.75 days was higher than the twice spraying by 51 days, which outperformed the treatment of once spraying by 51.25 days.
Table (2) also displays the significant effect of foliar spraying with potassium in reaching the stage of fruit ripeness, as all treatments significantly exceeded the treatment of the control, which required 151 days. The increase in the number of spraying times also led to significant differences between the treatments. Where the treatment of three-time spraying (by 147.50 days) outperformed the treatment of twice spraying (by 
148.75 days), which outperformed the treatment of once spraying (by 149.50 days).

Also, the increase in the number of spraying with potassium had a significant effect in increasing the number of total flowers and the percentage of hermaphrodite flowers. As the total number of flowers in the control reached 287.33, of which $25.75 \%$ were hermaphrodites. The treatment of once spraying achieved a significant superiority over the treatment of the control, where the total number of flowers was 362.75 and the percentage of hermaphrodite flowers was $38.94 \%$. The treatment of twice spraying achieved a significant superiority over the treatment of once spraying, and the number of total flowers in it reached 424.93, of which $40.75 \%$ were hermaphroditic. While the treatment of the three-time spraying outperformed all the treatments, with a total number of flowers of 449.97 , where $41.66 \%$ of which were a hermaphrodite (Table 2).

The spraying and the increase in the number of spraying times had a clear significant effect on the percentage of fruitset, as the fruit-set rates reached $21.62 \%, 33.25 \%, 35.50 \%$ and $36.23 \%$, in the control, the once spraying treatment, the twice spraying treatment, and the three-time spraying treatment, respectively. The differences were significant between all the treatments, (Table 2).

The results of the statistical analysis according to Table (2) showed the significant effect of increasing the number of spraying times on the weight of the peel and the weight of the internal tissues of the fruit, as their weight in the control reached $60.99 \mathrm{~g}$ and $59.12 \mathrm{~g}$, respectively. All treatments of the foliar spraying with potassium achieved a significant superiority over the control treatment, as the weight of the peel was $79.84 \mathrm{~g}$ and the internal tissue weight was $73.37 \mathrm{~g}$ in the treatment of three-time spraying. While in the twice spraying, the weight of the peel was $77.56 \mathrm{~g}$ and the weight of the internal tissues $71.17 \mathrm{~g}$. Whereas, in the treatment of once spraying, the peel weight was $75.60 \mathrm{~g}$ and the internal tissue weight was $65.12 \mathrm{~g}$. The differences were significant between all treatments.

Table (2) shows the significant positive effect of spraying and the increase in the number of spraying times on increasing the weight of the seeds, compared to the control in which the weight of the seeds reached 136.01g.The treatment of once spraying outperformed the control, and the weight of the fruits in it was $181.93 \mathrm{~g}$.Also, the treatment of twice spraying achieved a significant increase over the treatment of once spraying, with a weight of fruits of 201.16g. Similarly, the treatment of three-time spraying achieved a significant increase over the treatment of twice spraying, and outperformed all treatments, with a weight of $218.13 \mathrm{~g}$.
Spraying and increasing the number of spraying times had a significant effect on increasing the weight and diameter of the fruit, as the weight of the fruit in the control reached $256.12 \mathrm{~g}$, and the diameter was $8.32 \mathrm{~cm}$. The treatment of once spraying achieved a significant difference on the control, and the weight of the fruit in it reached $322.65 \mathrm{~g}$ and the diameter of the fruit was $11.20 \mathrm{~cm}$. Likewise, the treatment of twice spraying achieved a significant difference compared to the treatment of once spraying, where the weight of the fruit in it was $349.89 \mathrm{~g}$ and the diameter of the fruit was $11.38 \mathrm{~cm}$. The treatment of three-time spraying achieved a significant difference on the treatment of the twice spraying, with a weight of the fruit of $371.34 \mathrm{~g}$ and a diameter of the fruit of $11.71 \mathrm{~cm}$ (Table 2).

Table (2) also shows the significant effect of spraying and increasing the number of spraying times in the proportion of juice, as this percentage in the treatments reached $27.32 \%$, $38,27 \%, 40.37 \%$, and $41.54 \%$ in the control, the treatment of once spraying, the treatment of twice spraying, and the treatment of three-time spraying, respectively. The treatment of three-time spraying outperformed all treatments, and the differences were significant between all of these treatments.

Foliar spraying with potassium decreased the acidity of the juice (an increase in the $\mathrm{pH}$ value), while the $\mathrm{pH}$ value was 2.98 in the control. The increase in the number of spraying times achieved clear significant differences in this characteristic between the spraying treatments themselves. The treatment of once spraying significantly exceeded that of the control, with a $\mathrm{pH}$ value of 3.31.The treatment of twice spraying outperformed the treatment of once spraying with a $\mathrm{pH}$ value of 3.36. Whereas the treatment of three-time spraying outperformed all treatments, with a $\mathrm{pH}$ value of 3.45 (Table 2).

The percentage of T.S.S. also increased due to the effect of foliar spraying with potassium, as its value in the control reached $15.22 \%$.All the treatments were significantly superior on the control treatment, as the T.S.S. percentage in the treatment of three-time spraying reached $16.58 \%$, which was significantly superior to the treatment of twice spraying, in which the percentage of T.S.S. was $16.05 \%$, which was significantly superior to the treatment of once spraying, in which the T.S.S. percentage reached $15.72 \%$, (Table 2).

Table (2) indicates the significant effect of increasing the number of spraying times with potassium on the productivity of the French pomegranate variety, as the productivity in the control reached $11.36 \mathrm{~kg} /$ tree. The treatment of once spraying achieved a significant increase over the control, with a productivity of $12.66 \mathrm{~kg} /$ tree. The treatment of the twice spraying achieved a significant superiority over the treatment 
ISSN (online): 2581-3048

Volume 5, Issue 5, pp 1-9, May-2021

https://doi.org/10.47001/IRJIET/2021.505001

of once spraying, with a productivity of $14.02 \mathrm{~kg} /$ tree. While the treatment of the three-time spraying significantly outperformed all the treatments, with a productivity of 14.58 $\mathrm{kg} /$ tree. The spraying treatments achieved an increase in productivity over the control by $111.44 \%, 123.42 \%$, and $128.35 \%$ in the treatments of once, twice, and three-time spraying, respectively. Our study is consistent with Sheikh and Manjula (2009), who indicated that foliar fertilization of pomegranate trees with potassium in several batches gave the highest productivity.
3.3 Effect of interaction between the spraying concentrations and spraying times with potassium on the studied characteristics

The interaction between the concentrations of spraying with potassium (concentration $1000 \mathrm{ppm}$, and the concentration $2000 \mathrm{ppm}$ ) and the number of spraying times with potassium (spraying once, spraying twice, and spraying three times) had a significant effect on the whole studied characteristics compared with the control (Table 3).

Table (3): Effect of interaction of the spraying concentrations and spraying times with potassium

\begin{tabular}{|c|c|c|c|c|c|c|c|c|c|}
\hline $\begin{array}{l}\text { Spraying } \\
\text { times }\end{array}$ & $\begin{array}{c}\text { Spraying } \\
\text { concentration }\end{array}$ & $\begin{array}{l}\text { fruit- } \\
\text { set } \\
(\%)\end{array}$ & $\begin{array}{c}\text { Peel } \\
\text { weight } \\
\text { (g) }\end{array}$ & $\begin{array}{l}\text { Fruit } \\
\text { weight } \\
\text { (g) }\end{array}$ & $\begin{array}{c}\text { Fruit } \\
\text { diameter } \\
\text { (cm) }\end{array}$ & $\begin{array}{l}\text { Juice } \\
\text { ratio } \\
(\%)\end{array}$ & $\begin{array}{c}\text { T.S.S. } \\
(\%)\end{array}$ & $\begin{array}{c}\text { Juice } \\
\text { pH }\end{array}$ & $\begin{array}{c}\text { Yield } \\
\text { (kg/tree) }\end{array}$ \\
\hline \multicolumn{2}{|c|}{ Control } & 21.62 & 60.99 & 256.12 & 8.32 & 27.32 & 15.22 & 2.98 & 11.36 \\
\hline \multirow[b]{2}{*}{1} & $1000 \mathrm{ppm}$ & 32.20 & 75.33 & 327.99 & 11.21 & 34.56 & 15.58 & 3.32 & 12.33 \\
\hline & 2000 ppm & 35.48 & 79.86 & 364.76 & 11.46 & 37.38 & 15.91 & 3.38 & 13.64 \\
\hline \multirow{2}{*}{2} & 1000 ppm & 35.14 & 77.36 & 352.80 & 11.32 & 35.65 & 15.60 & 3.36 & 13.17 \\
\hline & 2000 ppm & 37.37 & 81.66 & 374.13 & 11.74 & 39.17 & 16.60 & 3.44 & 15.74 \\
\hline \multirow{2}{*}{3} & 1000 ppm & 35.91 & 79.86 & 372.30 & 11.56 & 37.20 & 16.25 & 3.44 & 13.78 \\
\hline & 2000 ppm & 37.84 & 83.67 & 381.16 & 12.19 & 40.43 & 17.10 & 3.54 & 16.30 \\
\hline \multicolumn{2}{|c|}{$\mathbf{L S D}_{5 \%}$} & 2.08 & 1.33 & 3.86 & 0.22 & 0.48 & 0.38 & 0.04 & 1.10 \\
\hline
\end{tabular}

The binary interaction of concentrations B and three-time spraying outperformed the other interactions, in the fruit-set ratio with a value of $37.84 \%$, in the weight of the fruit peel with a value of $83.67 \mathrm{~g}$, in the weight of the fruit with a value of $381.16 \mathrm{~g}$, in the diameter of the fruit with a value of 12.19 $\mathrm{cm}$, in the proportion of juice with a value of $40.43 \%$, in the percentage of T.S.S. with a value of $17.10 \%$, in the acidity of juice with a value of 3.54 , and in the total productivity per tree by $16.30 \mathrm{~kg}$. Then came the binaries of concentration B with the twice spraying, concentration B with once spraying, concentration A with three-time spraying, concentration A with the twice spraying, and finally, concentration A with once spraying, respectively, in most of the studied characteristics. These results show the greater effect of the potassium spraying concentration factor compared to the potassium spraying times factor, as doubling the spraying concentration achieved greater effectiveness and led to the improvement of the studied characteristics compared to the increase in the number of spraying times.

\subsection{Effect of spraying with potassium on the fruit cracking}

Foliar spraying with potassium significantly reduced the percentage of fruit cracking compared to the control (Fig. 1), as the percentage of cracked fruits in the control reached $73.96 \%$. The treatment of concentration A (1000 ppm) achieved a significant decrease compared to the control with a percentage of cracked fruits of $22.98 \%$. Also, the treatment of concentration B (2000 ppm) achieved a significant reduction in the percentage of fruit cracking compared to the treatment of concentration A, which amounted to $19.75 \%$, (Fig. 1).

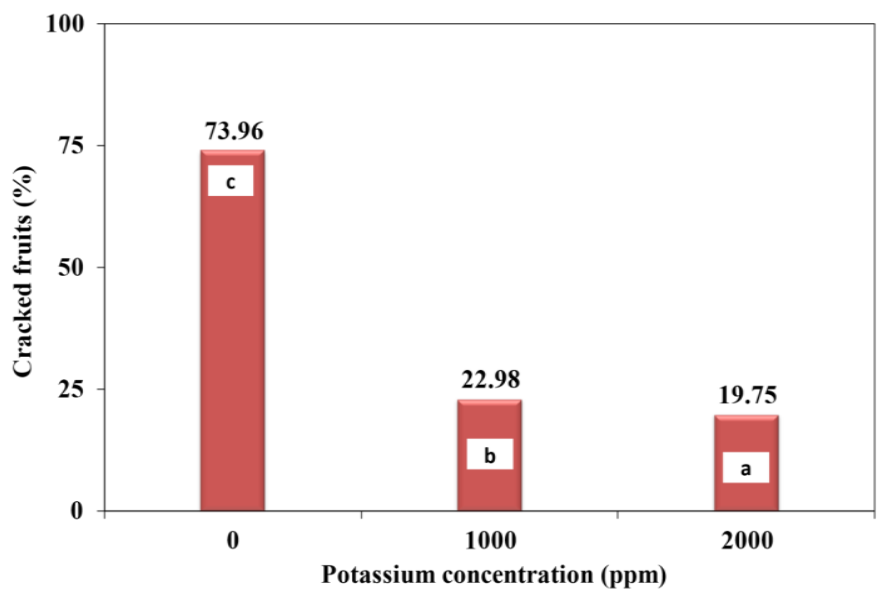

Figure 1: Effect of spraying concentration with potassium on the fruit cracking $\left(\mathrm{LSD}_{5} \%=0,24\right)$

Also, spraying and increasing the number of spraying times had a significant effect in reducing the percentage of cracked fruits compared to the control. The once spraying achieved a significant decrease over the control, which the percentage of cracked fruits in it reached $28.32 \%$. While the treatment of twice spraying achieved a significant decrease in the cracking rate, which amounted to $21.03 \%$ compared to the treatment of once spraying. The largest decrease in the percentage of cracked fruits was in the treatment of three-time spraying, as the percentage of cracked fruits in this treatment 
ISSN (online): 2581-3048

reached $17.57 \%$, which exceeded significantly on all treatments, (Fig. 2).

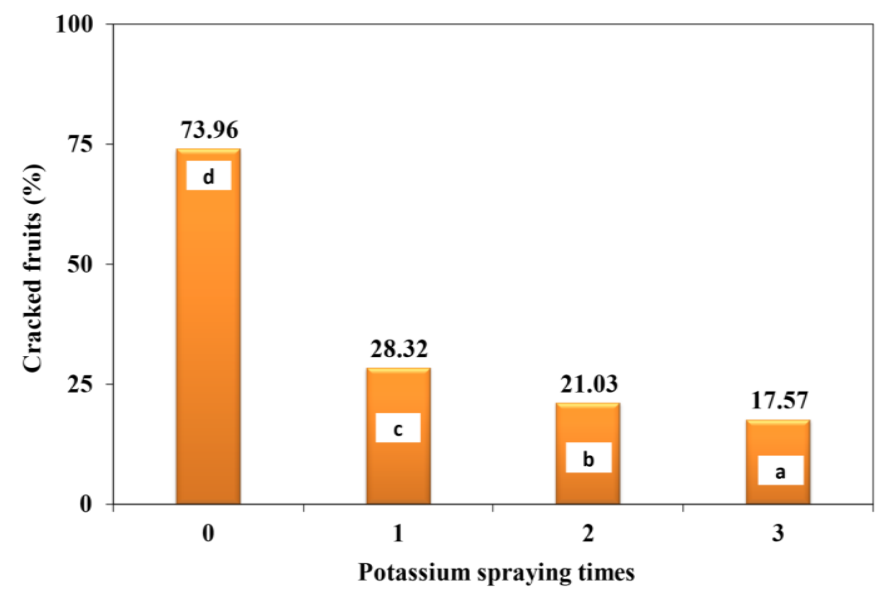

Figure 2: Effect of spraying times with potassium on the fruit cracking $\left(\mathbf{L S D}_{5} \%=\mathbf{0 . 3 5}\right)$

As for the interaction between the concentrations of spraying with potassium $(0,1000$, and $2000 \mathrm{ppm})$ and the number of spraying with potassium $(0,1,2$, and 3 spraying times), the effect was significant in reducing the percentage of fruit cracking of the French pomegranate variety compared to the control in which the rate of cracking was $73.96 \%$, (Fig. 3). The binary interaction of concentration B with the three-time spraying by $29.28 \%$ outperformed the other interactions, followed by the interaction of concentration $\mathrm{B}$ with the twice spraying by $35.44 \%$, followed by the interaction of concentration A with the three-time spraying by37.00\%, then the interaction of concentration A with the twice spraying by $44.56 \%$, then the interaction of concentration $\mathrm{B}$ with the once spraying by $46.44 \%$, then finally the interaction of concentration A with the once spraying by $49.66 \%$, where the differences were significant between all these interactions.

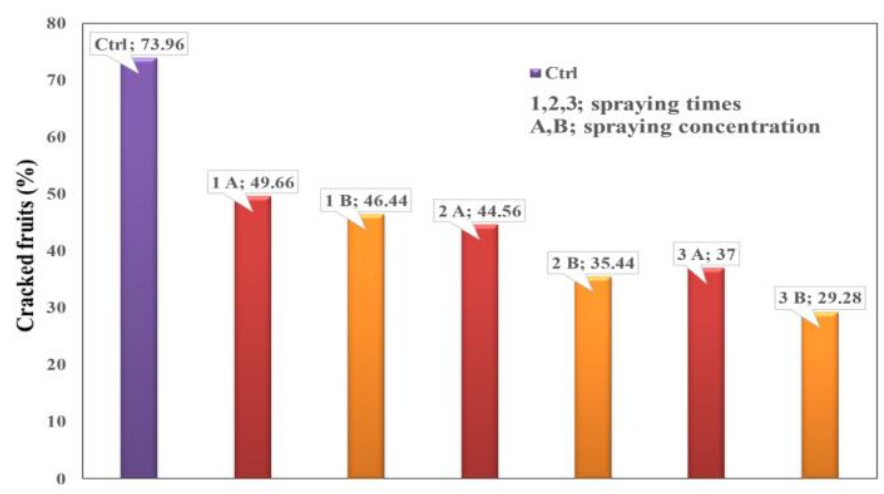

Figure 3: Effect of interaction between the spraying concentration and spraying times with potassium on the fruit cracking $\left(\mathrm{LSD}_{\mathbf{5}}=\mathbf{0 , 6 4}\right)$

Our results coincide with many studies that have shown the importance of foliar spraying with potassium in reducing the rate of cracking of pomegranate fruits and their negative effects. Nijjar et al. (1972) indicated that the effective effects of potassium may depend on an increase in the rate of photosynthesis, which in turn improves the quality of the fruits. Singh et al. (1990) indicated that fertilizing with potassium nitrate on pomegranate trees (Kandhari and Beedana varieties) has a positive effect in reducing the rate of fruit cracking, as the cells formed in the presence of potassium have thick walls and are durable and resistant to pressure exerted on them from the inside compared to the plant that suffers from its deficiency. In addition to the role of potassium in regulating water content, improving dehydration resistance, building cellulose in cell walls, and obtaining a strong and flexible shell (Hopkins, 2004; Nijjar, 1985). Padmavathamma and Hulamani (1998) indicated the effect of nitrogen and potassium nutrition on growth and production of the Jyoti and Pcr-1 pomegranate varieties, as nitrogen was added in the form of urea, and potassium in the form of potassium chloride. The results indicated that the individual spraying of $\mathrm{N}$ and $\mathrm{K}$ and the combined treatment led to increase plant height, branching, and productivity. Pareek (1981) and pareek (1987) confirmed that fertilization with nitrogen and potassium led to an increase in the average fruit weight. Sheikh and Manjula (2009) found that the addition of $\mathrm{N}, \mathrm{P}, \mathrm{K}$ fertilizers in 3 batches $(200 ; 200 ; 400 \mathrm{~g} / \mathrm{plant})$ gave the highest productivity of the pomegranate tree, the average weight of the fruit, and the percentage of juice, as well as an increase in the percentage of T.S.S., sugars, and vitamin C, compared to the number of fewer additions. Singh et al. (1988) showed that the use of a mixture of $\mathrm{N}, \mathrm{P}, \mathrm{K}$ led to a remarkable increase in the physiochemical composition of pomegranate fruits, as the quality of fruits, fruit-set, and production improved.

\section{CONCLUSIONS}

1) All treatments of spraying with potassium outperformed the control treatment in most of the studied traits (early flowering and ripening time, increasing the percentage of fruit-set, improving the characteristics of fruits).

2) The increase in the number of spraying times with potassium had a significant effect in increasing the yield compared to the control. The increase was $111.44 \%, 123.42 \%$, and $128.35 \%$ in the treatment of once, twice, and three-time spraying, respectively.

3) The increase in the number of spraying times with potassium reduced the ratio of fruit cracking compared to the control, as it reached $28.32 \%$, $21.03 \%, 17.57 \%$, in the treatment of once, twice, and three-time spraying, respectively.

4) The increase in the potassium concentration had a significant positive effect in increasing the yield compared to the control. Wherever, the increase was 
$115.23 \%$ and $134.07 \%$ in the treatments of concentrations $\mathrm{A}$ and $\mathrm{B}$, respectively.

5) The increase in the potassium concentration led to a reduction in the ratio of fruit cracking compared to the control, as it was $22.98 \%$ and $19.75 \%$ in the treatments of concentrations $\mathrm{A}$ and $\mathrm{B}$, respectively.

\section{REFERENCES}

[1] Abd I.E, Rahman E.I. (2010). Physiological studies on cracking phenomena of pomegranate. J. AppI. Sci. Res. 6:669-703.

[2] Abdel-Aziz F.A, Ahmed F.F, Mosry M.H. (2001). Relation of potassium, Calcium and Boron with productivity and fruit cracking of Manfalouty pomegranate trees. The fifth Arabian Hort. Conference, Ismailai, Egypt, March: 24-28.

[3] Anonymous A. (1983). Second National workshop. Arid zone fruit Research Technology. Dec. 10-13.

[4] Bankar G.J, Prasad R.N. (1992). Performance of important pomegranate cultivars in arid region. Annals of arid Zone 31(3): 181-183.

[5] Chandra R, Suroshe S, Sharma J, Marathe R.A, Meshram D.T. (2011). Pomegranate growing manual. NRS on pomegranate, Solapur. 1-58.

[6] Draie R, Aboras A. (2021a). Effect of Irrigation on Cracking of Pomegranate Fruits (French Variety). International Research Journal of Innovations in Engineering and Technology, IRJIET, 5(2): 24-33.

[7] Draie R, Aboras A. (2021b). Effect of Foliar Spraying with Gibberellic Acid on Fruit Cracking of Pomegranate (Punica granatum L). International Research Journal of Innovations in Engineering and Technology, IRJIET, 5(2): 53-62.

[8] Fayed T.A. (2010). Effect of compost tea and some antioxidant applications on leaf chemical constituents, yield and fruit quality of pomegranate. World J. Agric. Sci., 6(4): 402-411.

[9] Finkel T, Holbrook N.J. (2000). Oxidants, oxidative stress and the biology of ageing. Nature 408:239-247.

[10] Galindo A, Rodriguez P, Gollado-Gonzalez J, Cruz Z, Torrecillas E, Ondono S, Corell M, Moriana A, Torrecillas A. (2014). Rainfall intensifies fruit peel cracking in water stressed pomegranate trees. Agric. Meteorol. 194: 29-35.

[11] Gharesheikhbayat R. (2006). Anatomical study of fruit cracking in pomegranate c.v. Malas-e-Torsh. PajoheshSazandegy 69: 10-14.

[12] Hoda A.K, Hoda S.H.A. (2013). Cracking and fruit quality of pomegranate (Punica granatum L.) as affected by pre-harvest sprays of some growth regulators and mineral nutrients. J. Hortic. Sci. Ornamental plants 5: 71-76.
[13] Hopkins W.G. (2004). Introduction to plant physiology.2th Edition New York: John Wiley and Sons, Inc: 320-325.

[14] Khadivi-Khub A. (2014). Physiological and genetic factors influencing fruit cracking. Acta physiol. Plant. 37: 1-14.

[15] Khalil H.A, Aly H.S. (2013). Cracking and fruit quality of Pomegranate (Punica granatum L.) as affected by pre-harvest sprays of some growth regulators and mineral nutrients. J. Hortic. Sci. Ornam plants 5: 71-76.

[16] Malhotra V.K, Khajuria H.N, Jawanda J.S. (1983). Studies on physio-chemical characteristics. 1physical characteristics. Punjab Hort. J. 23: 153-157.

[17] Nijjar G.S, Deol S.S, Bajw M.S. (1972). Effect of Nitrogen, Phosphorus and Potassium on vigour, cropping and quality of New Castel apricot. Res. Punjab. Agric. University, 9: 261-263.

[18] Nijjar G.S. (1985). Nutrition of fruit trees. Usha Raj Kumar Kalyani, New Delhi: 79-119.

[19] Ozkaya M.T. (2004). The effect of some foliar fertilizers, Applied in different period on quality and yield in gemlike olive (Olea europaea L.) Variety Turkish. Ankara Univ. Faculty of Agric. Depart of Hort. Ankara. 10(3): 353-357.

[20] Padmavathamma A.S, Hulmaani N.C. (1998). Effect $\mathrm{N}, \mathrm{K}$ Nutrition growth yield pomegranate cv jyoti RCRI. Karnataka journal Agri. Sciences: 1126-1128.

[21] Panwar S, Desair U.T, Chouduhary S.M. (1994). Effect of pruning on physiological disorder in pomegranate. Annals of Arid Zone 33: 83-84.

[22] Pareek O.p. (1981). Report for ber, date plam, pomegranate, fig, custard apple, etc., (1976-80). All India Co-ordinated Fruit improvement project, ICAR cell 111, Hissar Technical Document: 12-20.

[23] Pareek O.P. (1987). Annual Report. All India Coordinated Fruit improvement project, ICAR coordinating cell, Hissar Technical Document: 25p.

[24] Prasad R.N, Bankar G.J, Vashishtha B.B. (2003). Effect of drip irrigation on growth, yield and quality of pomegranate in arid region. Indian J. Hort. 60: 140-142.

[25] Saad F.A, Shaheen M.A, Tawfik H.A. (1988). Anatomical stydy cracking pomegranate fruit. Alexandria Journal of Agri. Research, 33(1): 155166.

[26] Saei H, Sharifanni M.M, Dehghanic A, Esmaeil S, Vahid A. (2014). Description of biomechanical forces and physiology parameters of fruit cracking in pomegranate. Scientia Hortic. 178: 224-230.

[27] Schrader L, Zhang J, Sun J. (2002). Environmental Stresses that cause sunburn of apple. XXVI. 
ISSN (online): 2581-3048

Volume 5, Issue 5, pp 1-9, May-2021 https://doi.org/10.47001/IRJIET/2021.505001

International Horticultural congress \& Exhibition, Toronto 11: 397-405.

[28] Shaheen S.A.A. (1995). Effect of foliar sprays of some nutrients on flowering and fruiting of olive trees. M. SC. Thesis. Fac. of Agric. Cairo unir, 122p.

[29] Sheikh M.K, Manjula N. (2009). Effect Split application N.K on growth fruiting ganesh pomegranate Acta. Hort. 213-218.

[30] Shulman S, Fainberstein L, Lavee S. (1984). Pomegranate fruit development and maturation. J. Hortic. Sci. 59: 265-282.

[31] Singh D.B, Kingsly A.R.P, Jain R.K. (2006). Controlling fruit cracking in pomegranate. Indian Hort. 51(1): 14-32.

[32] Singh R.P.; Sharma Y.P.; Awasthi R.P. (1990). Influence of different cultural practices on premature fruit cracking of pomegranate. Progressive Hort. 22(1-4): 92-96.

[33] Singh R.R, Singh H.G, Chauhan K.S. (1987). Effect N-P-K physico-chemical composition pomegranate fruit local selection. Progressive Horticulture. 77-79.

[34] Singh R.R, Singh H.G, Chauhan K.S. (1988). Effect of $\mathrm{N}, \mathrm{P}$ and $\mathrm{K}$ on physicochemical composition of pomegranate fruit local selection. Progressive Horticulture. 19: 77-79.

[35] Singh S.P. (1995). Pomegranate in commercial fruits. pp. kalyani publisher, Ludhiana: 225-233.

[36] Yazici K, Kaynak L. (2006). Effect air temperature relative humidity solar radiation fruit surface temperatures sunburn damage pomegranate Punica granatum L. c.v. Hicaznar. Acta. Hort. 181-186.

\section{Citation of this Article:}

Dr. Rida DRAIE; Ali ABORAS, "Importance of Applying Potassium to Reduce the Cracking Rate of Pomegranate Fruits" Published in International Research Journal of Innovations in Engineering and Technology - IRJIET, Volume 5, Issue 5, pp 19, May 2021. Article DOI https://doi.org/10.47001/IRJIET/2021.505001 